\title{
Dose-dependent effects of pentabrominated diphenyl ethers on sexual hormone and histology of male reproductive system in rats
}

\author{
Lingyan Yuan, Meiqing Fan, Ping Zhan* \\ Department of Environment Hygiene, Chongqing Medical University, Chongqing, China \\ Email: "zanpingcqums@163.com
}

Received March 22 ${ }^{\text {nd }}, 2012$; revised April 9 ${ }^{\text {th }}, 2012$; accepted April 13 ${ }^{\text {th }}, 2012$

\begin{abstract}
Polybrominated diphenyl ethers (PBDEs) used as flame retardants are widely used in a variety of consumer products, like textiles, foam and building materials. They are persistent in the environment, and increasing levels of PBDEs have been found both biota and human tissue samples. In the present study we examined the dose-dependent effects of pentabrominated diphenyl ether (PBDE-99) on the serum hormone and histology of reproductive system in male rats. 40 health 4-week-old SD rats were divided into 4 groups randomly. The treated rats were orally administered with BDE-99 at the dose of 60,120 or $180 \mathrm{mg} / \mathrm{kg}$, while controls received equal volume of corn oil. We examined the changes of serum hormone levels, histopathology, and PCNA after 30 days exposure to BDE-99. With increasing doses of BDE-99, testis organ coefficient increased, serum hormone levels lower, PCNA positive expression reduced, and the degeneration of seminiferous epithelium were revealed in treated group. These indicators with significant dose-effect relationship showed that BDE-99 can reduce the serum sex hormone levels and cause severe degeneration of seminiferous epithelium.
\end{abstract}

Keywords: Pentabrominated Diphenyl Ethers; Male Reproductive System; the Relationship of Dose-Effect

\section{INTRODUCTION}

Polybrominated diphenyl ethers (PBDEs) are high-production-volume chemicals that have been widely used as flame retardants in a variety of consumer products including building materials, foam, transportation, furniture, household textiles, chemical engineering and electronic equipment [1]. Due to their high production volume, volatility, lipophilicity, persistence and bio-accu-

\footnotetext{
*Corresponding author.
}

mulation, PBDEs are regarded as ubiquitously occurring environmental contaminants [2]. PBDEs have been identified in various environmental sectors, including air, sewage sludge and sediment [3], biota including fish [4], mussels [5], fish-eating birds and marine mammals [6]. PBDEs have also been identified in human adipose tissue, breast milk and blood [7]. Fetuses and newborns have the highest body burden, owing to exposure through house dust and via breast milk [8]. PBDEs spread to distant areas through environmental media, causing pollution repeatedly [9].

Depending on the number and position of bromine atoms, PBDEs are categorized into 10 series of 209 homologues (PBDEs $=\mathrm{C}_{12} \mathrm{H}_{10-\mathrm{x}} \mathrm{Br}_{\mathrm{x}} \mathrm{O}(\mathrm{x}=1,2, \cdots, 10)$ ). The structural of PBDEs are similar to polychlorinated bi- phenyls (PCBs). Recent researches showed that several PBDE congeners, including decabromodiphenyl ethers (BDE-209), hexabromodiphenyl ethers (BDE-153), pen- tabromodiphenyl ethers (BDE-99), and tetrabromodi- phenyl ethers (BDE-47). Two of the most abundant con- geners of PBDEs in wildlife and humans are BDE-47 and BDE-99 [10]. PBDEs gave a low acute toxicity in animals. After chronic exposure, the target organs are the kidney, thyroid and liver [11]. Effects of PBDEs in ex- periment animals include endocrine disruption, neurode- velopmental and behavioral outcomes, hepatic abnor- malities, and possibly cancer [12]. About the mecha- nisms of neurotoxicity, some researchers think of PBDEs through phospholipase A2 pathway can stimulate the release of arachidonic acid, influence calcium homeosta- sis and induce displacement of protein kinase C [13]. PBDEs have also been reported to decrease levels of thyroid hormones $\left(\mathrm{T}_{4}\right)$, because of PBDEs may disturb thyroid hormone transport [14]. Previous studies in hu- man found that PBDEs can effect on lower birth weight and length [15], fertility [16], thyroid hormone homeo- stasis [17] and cryptorchidism [18]. Chao et al. reported that prenatal or postnatal exposure to PBDEs may delay the development of the neurological 
of infants and tod- dlers [19]. Female reproductive toxic effects of PBDEs have been reported. Postnatal exposure of rats to BDE-47 was reported to decrease the serum levels of estradiol and alterations in folliculogenesis [20]. Nevertheless, there is scant information regarding possible effects of PBDEs on male reproduction system.

This study is aim to gain insight into how BDE-99 effects on circulating levels of sex hormones, and the morphology of the testis, including histopathology, hisochemistry and its any potential mechanism.

\section{MATERIALS AND METHODS}

\subsection{Animals}

Forty male Sqarague-Dawley rats, 23 days old and weighing 40 - $60 \mathrm{~g}$, were purchased from the Institute of Surgery Research, Daping Hospital affiliated to the Third Military Medical University. The animals were housed in a room with a $12 \mathrm{~h} /$ dark and light cycle, room temperature at $25^{\circ} \mathrm{C} \pm 1{ }^{\circ} \mathrm{C}$, and humidity at $50 \% \pm 10 \%$. They were given free access to tap water and rat chow, for 5 days, to make them acclimatized to the new environment prior to study.

\subsection{Chemicals and Treatments}

BDE-99 (>99\%) was purchased from the Chemical Plant Cooperation of Kendu in Yantai of Shandong, prepared in corn oil and sonicated $30 \mathrm{~min}$ at $40^{\circ} \mathrm{C}$. SP histochemistry kit, proliferating cell nuclear antigen (PCNA) and diaminobenzidine (DAB) were purchased from a biotechnology company of Dingguo of Beijing. The BDE99 solution then was administered to rats at the volume of $1 \mathrm{~mL}$ corn oil $/ \mathrm{kg}$ BW.

The four-week-old male SD rats were randomly divided into four groups according to their bodyweight, of 10 rats in each group. Rats in treatment groups were orally gavaged with BDE-99 at the dose of 60,120 or $180 \mathrm{mg} / \mathrm{kg}$, respectively, for 30 days, while rats in the control group received an equal volume of corn oil for the same period of time.

After exposure, blood samples collected from infraorbital arterial were put in $37^{\circ} \mathrm{C}$ water bath for $30 \mathrm{~min}$, followed by centrifugation at $2500 \mathrm{rpm}$ for $10 \mathrm{~min}$, and serum samples were stored at $-20^{\circ} \mathrm{C}$.
Then, rats were killed by cervical dislocation. The testis were removed and weighed. Testis tissue samples were fixed in $4 \%$ paraformaldehyde, dehydrated in ethanol, embedded in paraffin. Serial sections were conducted at the interval thickness of $6 \mathrm{~mm}$, and stained with hermatoxylin and eosin (HE) for testis tissue morphology analysis and immunohistochemistry. All of the experiments were approved by the Animal Use and Care Committee.

\subsection{Serum Hormone Assay}

Serum levels of total testosterone (T) and estradiol $\left(E_{2}\right)$ were measured in duplicate by standard radioimmunoassay (RIA) kits. T, $\mathrm{E}_{2}$ standard radioimmunoassay kits were purchased from North Biology Technology Research Institute of Beijing. Coefficients of variance for all assays were below $10 \%$ in intra-assay and inter-assay.

\subsection{Histochemistry}

The staining sections of proliferating cell nuclear antigen (PCNA) immunohistochemistry were quantitatively analyzed by a picture analysis system: five points in each section were observed at 200× magnification, and "target gray value” was regarded as measurement parameters. The average of gray value in five points was the gray value of this staining section, which was divided into 256 level: 0 was darkest, and 256 was brightest.

\subsection{Statistical Analyses}

All data are presented as mean \pm standard deviation (SD). Analysis of variance (ANOVA) was performed using SAS for windows 8.1. A p $<0.05$ was considered statistically significant.

\section{RESULTS}

\subsection{Testis Organ Coefficient}

Testis organ coefficient is a ratio of the weight of testis per $100 \mathrm{~g}$ of the body weight, which is a frequent observation in sub-acute and sub-chronic toxicity studies. After 30 days of exposure to BDE-99, it was found that the organ coefficient in treated groups were significantly higher than that in the control (Table 1).

Table 1. Changes in organ coefficient in different dose groups.

\begin{tabular}{ccccc}
\hline & \multicolumn{3}{c}{ Dose group } \\
\cline { 2 - 4 } & Control & $60 \mathrm{mg} / \mathrm{kg}$ & $120 \mathrm{mg} / \mathrm{kg}$ & $180 \mathrm{mg} / \mathrm{kg}$ \\
\hline Organ coefficient & $1.249 \pm 0.045$ & $1.559 \pm 0.076^{*}$ & $2.313 \pm 0.058^{*}$ & $2.381 \pm 0.902^{*}$ \\
\hline
\end{tabular}

Notes: ${ }^{*}$ Compared with control group of same time, $\mathrm{p}<0.05$. 


\subsection{Serum Levels of Hormones}

Data of serum concentration of $\mathrm{T}$ and $\mathrm{E}_{2}$ in all groups are shown in Table 2. There was a significant correlation between the exposure groups and the control group (p < 0.05 ). We also made a correlation analysis between the dose of BDE-99 and the concentration of $\mathrm{T}$ and $\mathrm{E}_{2}$. Exposure dose was negatively correlated with the concentrations and there had statistically significant difference $(\mathrm{p}<0.05)$.

\subsection{Testicle Histopathology}

Histopathology of testicles in all the controls were normal and complete (Figure 1). Seminiferous tubules in BDE-99 exposed groups appeared the changes of degeneration and necrosis. The desquamation of the seminiferous epithelium and the decreased spermatozoa were also found in the treated groups. These alterations were severely appeared in $180 \mathrm{mg} / \mathrm{kg}$ group (Figure 2).

\subsection{Immunohistochemical Assay}

The positive expression cells of PCNA showed as brown in the nucleus, while negative in the cells appeared colorless. The positive cells were observed in seminiferous epithelium. The positive expression cells of PCNA in control group distributed diffusely, but the intensity of PCNA expression decreased from spermatogonia to sperm (Figure 3). The PCNA positive expression cells in all treatment groups were lower than the control (Figure 4). Results of PCNA expressing cells in all treatment groups are shown in Table 3 . The positive cells of PCNA in $120 \mathrm{mg} / \mathrm{kg}$ and $180 \mathrm{mg} / \mathrm{kg}$ group expressed significantly lower than control group $(\mathrm{p}<0.05)$. However, there was no difference between $60 \mathrm{mg} / \mathrm{kg}$ group and control group $(\mathrm{p}>0.05)$.

\section{DISCUSSION}

With the progress of the study, SD rats gradually matured. At this period, testosterone synthesized and secreted by Leydig cells reach a higher level and it is essential for the regulation of the male reproductive function. Blanco and Martinez reported that low level of testosterone may lead to detachment of germ cells from seminiferous epithelium and may lead to germ cell apoptosis. According to our findings, the levels of testosterone and estradiol in treatment groups were decreased and showed a dose-dependent relationship [21]. That means when exposured to the low dose of BDE-99, it

Table 2. Serum $\mathrm{T}, \mathrm{E}_{2}$ concentrations in different dose groups.

\begin{tabular}{ccccr}
\hline & \multicolumn{4}{c}{ Dose group } \\
\cline { 2 - 5 } & Control & $60 \mathrm{mg} / \mathrm{kg}$ & $120 \mathrm{mg} / \mathrm{kg}$ & $180 \mathrm{mg} / \mathrm{kg}$ \\
\hline $\mathrm{T}$ & $13.911 \pm 1.106$ & $9.996 \pm 0.959^{*}$ & $8.138 \pm 2.485^{*}$ & $5.802 \pm 1.141^{*}$ \\
$\mathrm{E}_{2}$ & $0.572 \pm 0.090$ & $0.246 \pm 0.074^{*}$ & $0.117 \pm 0.011^{*}$ & $0.047 \pm 0.012^{*}$ \\
\hline
\end{tabular}

Notes: ${ }^{*}$ Compared with control group, $\mathrm{p}<0.05$.

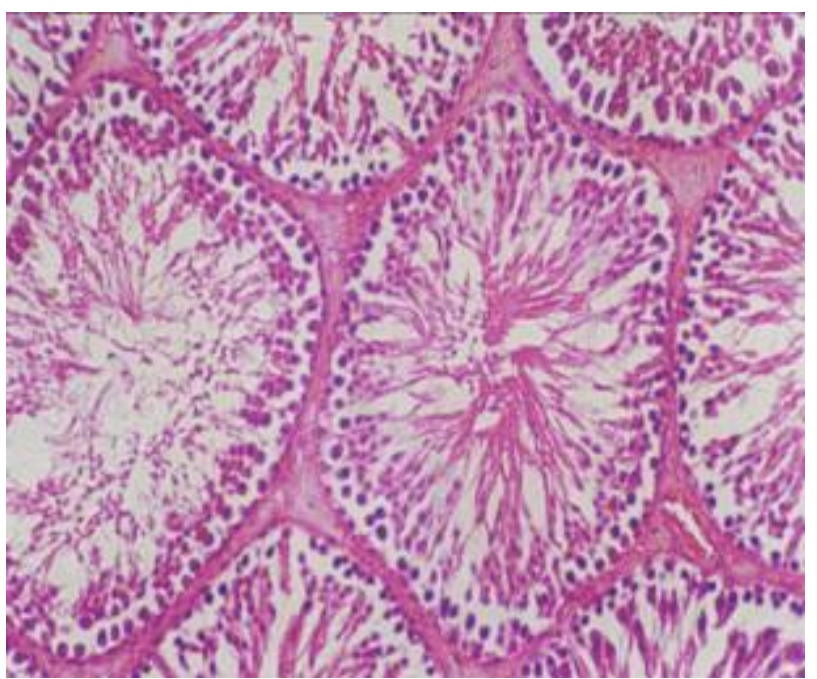

Figure 1. Normal testis tissue (control) hematoxylin-eosin stain $(\times 400)$.

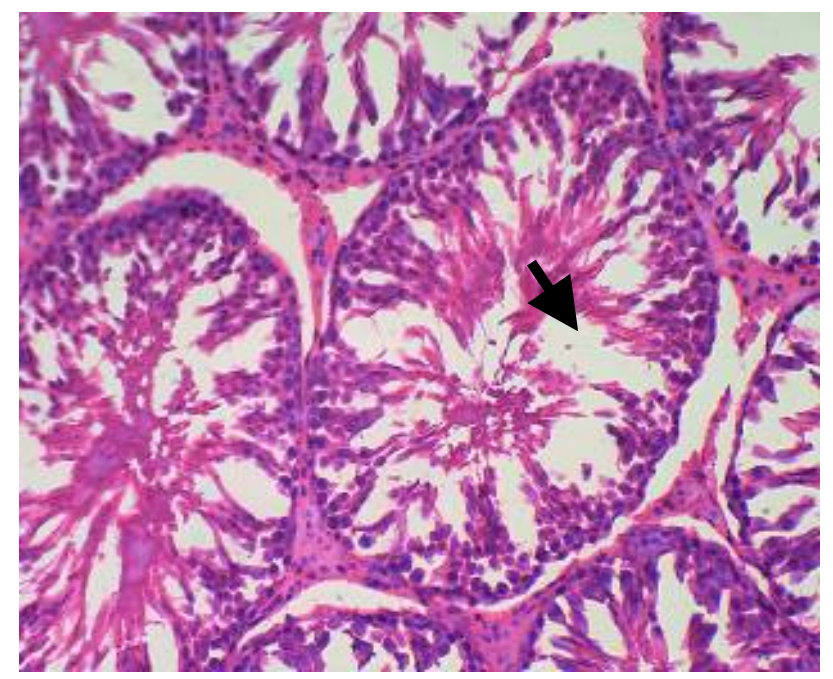

Figure 2. Showing stratified epithelium (experiment) hematoxylineosin stain $(\times 400)$. 


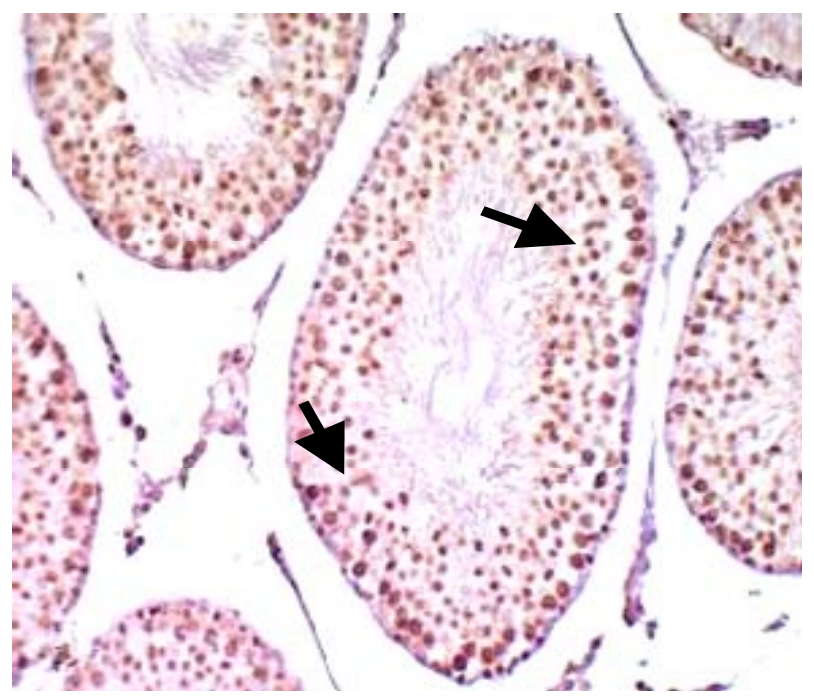

Figure 3. Showing (PCNA) positive cells (control) hematoxylineosin stain $(\times 400)$.

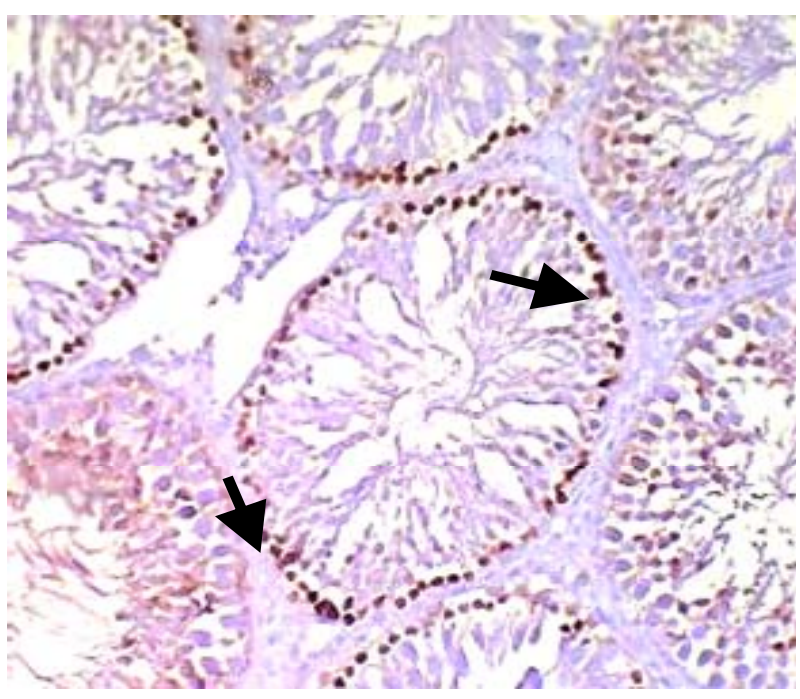

Figure 4. Showing (PCNA) positive cells (treatment) hematoxylineosin stain $(\times 400)$.

Table 3. Immunohistochemical analysis of PCNA expression in testis.

\begin{tabular}{|c|c|c|c|c|}
\hline & \multicolumn{4}{|c|}{ Dose group } \\
\hline & control & 60 mg/kg & 120 mg/kg & 180 mg/kg \\
\hline PCNA & $116.668 \pm 1.438$ & $119.098 \pm 1.97$ & $159.15 \pm 3.031^{*}$ & $182.052 \pm 2.002^{*}$ \\
\hline
\end{tabular}

Notes: *Compared with control group, $\mathrm{p}<0.05$.

had caused irreversible damage on leyding cell function. The changes of organ coefficient can reflex that if the organ have hyperplasia, hypermia, edema, or atrophy. So this may explain the increase of organ coefficient in treated group.

The changes of histopathological in testicular gradually altered severely with the dose raised. We observed that BDE-99 induced atrophy and degeneration in seminiferous tubules.The reason of changes may be due to the decrease in testosterone levels in the serum. Vacuolations formed by the loss of germ cells were observed in sertoli cells in $180 \mathrm{mg} / \mathrm{kg}$ group. Vacuolization of sertoli cells may be owing to the change of cellular permeability [22]. Otherwise, based our founding, PCNA expression decreased which affected the development and generation of spermatocytes. So sperm cells developed delay, and caused spermatogenic function decreased finally. In short, BDE-99 affect the function of sperm cell, and cause sex hormones decreased, mature and differentiation of sperm delayed and the alteration in PCNA. All the results show clearly that BDE-99 can affect the reproductive functions in male rats.

\section{CONCLUSION}

We observed that with increasing doses of BDE-99, testis organ coefficient increased, serum hormone levels lower, PCNA positive expression reduced, and the degeneration of seminiferous epithelium were revealed in treated group. These indicators with significant dose-effect relationship showed that BDE-99 can reduce the serum sex hormone levels and cause severe degeneration of seminiferous epithelium in rats.

\section{REFERENCES}

[1] Frederiksen, M., Vorkamp, K., Thomsen, M. and Knudsen, L.E. (2009) Human internal and external exposure to PBDEs-A review of levels and sources. International Journal of Hygiene and Environmental Health, 212, 109134. doi:10.1016/j.ijheh.2008.04.005

[2] Kodavanti, P.R.S. and Ward, T.R. (2005) Differential effects of commercial polybrominated diphenyl ether and polychlorinated biphenyl mixtures on intracellular signaling in rat brain in vitro. Toxicological Sciences, 85, 952-962. doi:10.1093/toxsci/kfi147

[3] Darnerud, P.O., Eriksen, G.S., Johannesson, T., Larsen, P.B. and Viluksela, M. (2001) Polybrominated diphenyl ethers: occurrence, dietary exposure, and toxicology. Environ Health Perspect, 109, 49-68. doi:10.1289/ehp.01109s149

[4] Christensen, J.H., Glasius, M., Pécseli, M., Platz, J. and Pritzl, G. (2002) Polybrominated diphenyl ethers (PBDEs) 
in marine fish and blue mussels from southern Greenland. Chemosphere, 47, 631-638. doi:10.1016/S0045-6535(02)00009-7

[5] DeWit, C.A. (1999) Brominated flame retardants in the environment-An overview. Organohalogen Compounds, 40, 329-332.

[6] Haglund, P.S., Zook, D.R., Buser, H.S. and Hu, J. (1997) Identification and quantification of polybrominated diphenyl ethers and methoxy-polybrominated diphenyl ethers in Baltic biota. Environmental Science and Technology, 31, 3281-3287. doi:10.1021/es9702834

[7] Mazdai, A., Dodder, N.G., Abemathy, M.P., Hites, R.A. and Bigsby, R.M. (2003) Polybrominated diphenyl ethers in maternal and fetal blood samples. Environmental Health Perspectives, 111, 1249-1252. doi:10.1289/ehp.6146

[8] Zhou, T., Taylor, M.M., et al. (2002) Developmental exposure to brominated diphenyl ethers results in thyroid hormone disruption. Toxicological Sciences, 66, 105-116. doi:10.1093/toxsci/66.1.105

[9] Zhao, Y.X., Qin, X.F. and Li, Y. (2009) Diffusion of polybrominated diphenyl ether (PBDE) from an E-waste recycling area to the surrounding regions in Southeast China. Chemosphere, 76, 1470-1476. doi:10.1016/j.chemosphere.2009.07.023

[10] Prasada, R.S., et al. (2005) Polybrominated diphenyl ether (PBDE) effects in rat neuronal cultures: ${ }^{14} \mathrm{C}-\mathrm{PBDE}$ accumulation, biological effects, and structure-activity relationships. Toxicological Sciences, 88, 181-192. doi:10.1093/toxsci/kfi289

[11] Costa, L.G., Giordano, G., Taqliaferri, S., Caqlieri, A. and Mutti, A. (2008) Polybrominated diphenyl ether (PBDE) flame retardants:environmental contamination, human body burden and potential adverse health effects. Acta Biomed, 79, 172-183.

[12] Darnerud, P.O. (2008) Brominated flame retardants as possible endocrine disrupters. International Journal of Andrology, 31, 152-160. doi:10.1111/j.1365-2605.2008.00869.x

[13] Kodavanti, P.R. and Ward, T.R. (2005) Differential effects of commercial polybrominated diphenyl ether and polychlorinated biphenyl mixtures on intracellular signaling in rat brain in vitro. Toxicological Sciences, 85, 952-962. doi:10.1093/toxsci/kfi147

[14] Meerts, I., Zanden, J.J. and Luijkis, E.A.C. (2000) Potent competitive interactions of some polybrominated flame retardants and related compounds with human transthyretin in vitro. Toxicological Sciences, 56, 95-104. doi:10.1093/toxsci/56.1.95

[15] Chao, H.R., Wang, S.L., Lee, W.J., Wang, Y.F. and Papke, O. (2007) Levels of polybrominated diphenyl ethers (PBDEs) in breast milk from central Taiwan and their relation to infant birth outcome and maternal menstruation effects. Environment International, 33, 239-245. doi:10.1016/j.envint.2006.09.013

[16] Akutsu, K., Takatori, S., Nozawa, S., Yoshiike, M., Nakazawa, H., Hayakawa, K., Makino, T. and Iwamoto, T. (2008) Polybrominated diphenyl ethers in human serum and sperm quality. Bulletin of Environmental Contamination and Toxicology, 80, 345-350. doi:10.1016/j.reprotox.2011.02.005

[17] Turyk, M.E., Persky, V.W., Imm, P., Knobeloch, L., Chat- terton, R.J. and Anderson, H.A. (2008) Hormone disruption by PBDEs in adult male sport fish consumers. Environmental Health Perspectives, 116, 1635-1641. doi:10.1289/ehp.11707

[18] Main, K.M., Kiviranta, H., Virtanen, H.E., Sundqvist, E., Tuomisto, J.T., Tuomisto, J., Vartiainen, T., Skakkebaek, N.E. and Toppari, J. (2007) Flame retardants in placenta and breast milk and cryptorchidism in newborn boys. Environmental Health Perspectives, 115, 1519-1526.

[19] Chao, H.R., Tsou, T.C. and Huang, H.L. (2011) Levels of breast milk PBDEs from southern Taiwan and their potential impact on neurodevelopment. Pediatric Research, 70, 596-600. doi:10.1203/PDR.0b013e3182320b9b

[20] Talsness, C.E., Kuriyama, S.N. and Sterner-Kock, A. (2008) In utero and lactational exposure to low doses of polybrominated diphenyl ether-47 alter the reproductive system and thyroid gland of female rat offspring. Environmental Health Perspectives, 116, 308-314. doi:10.1289/ehp.10536

[21] Blanco-Rodriguez, J. and Martinez-Garcia, C. (1998) Apoptosis precedes detachment of germ cells from the seminiferous epithelium after hormonal suppression by short-term oestradiol treatment of rats. International Journal of Andrology, 21, 109-115.

[22] Kumar, S.G., Narayana, K. and Bairy, K.L. (2006) Dacarbazine induces genotoxic and cytotoxic germ cell damage with concomitant decrease in testosterone and increase in lactate dehydrogenase concentration in the testis. Mutation Research, 607, 240-252. doi:10.1016/j.mrgentox.2006.04.019 